\title{
Developing Entrepreneurial Curriculum in Indonesian Islamic Higher Education: A Transformation Process
}

\author{
Achmad Room Fitrianto ${ }^{1,2,3}$, Abd A'la ${ }^{4}$ \\ ${ }^{1}$ The Islamic Entrepreneurial and Business Development Centre, State Islamic University of Sunan Ampel, \\ Surabaya, Indonesia \\ ${ }^{2}$ Indonesia Islamic Economic Department, State Islamic University of Sunan Ampel, Surabaya, Indonesia \\ ${ }^{3}$ The School of Social Science and International Studies Humanities Faculty, Curtin University, Bentley, Australia \\ ${ }^{4}$ State Islamic University of Sunan Ampel, Surabaya, Indonesia \\ Email: ar.fitrianto@uinsby.ac.id, rektor@uinsby.ac.id
}

Received 24 September 2014; revised 20 October 2014; accepted 12 November 2014

Copyright (C) 2014 by authors and Scientific Research Publishing Inc.

This work is licensed under the Creative Commons Attribution International License (CC BY).

http://creativecommons.org/licenses/by/4.0/

(c) (i) Open Access

\section{Abstract}

Entrepreneurship is believed as a method that could change people mindset, behavior, and attitude. In this term, the entrepreneurship position is between education and economic issues. Many people have thought that only an entrepreneur who has entrepreneurial spirit, as a hereditary, that formed by his ancestor. Therefore, some people believe that an entrepreneur does not need a high education degree. As consequences, the scope of entrepreneurship will be understood as the domain of the rich, and poor people are prohibited to become entrepreneur. What is more, the community has general views that becoming wealth and rich is a symbol of entrepreneurial success. However, the fact shows rich and wealth is not the one and only indicator of the entrepreneurship aim. It is a stepping stone to achieve a better life and future. Whether an entrepreneur can be created or not, the role of universities cannot be ignored. UIN Sunan Ampel that framed to become of one of the Islamic Higher educations that develops entrepreneurship in the frame of Islamic Studies, has an interesting experience. This experience would be useful to be shared with other agencies in setting up their institutions more adaptable with entrepreneurial spirit. There are many challenges that should be faced solved.

\section{Keywords}

Entrepreneurial Education, Strategic Planning, Islamic Higher Education, Young Muslim Entrepreneur 


\section{Introduction}

Indonesia experienced the highest economic growth ever in 1976-1981. In average, Indonesia had 7\% - 12\% annual growth and reached the peak of economic growth in 1982 by 13.5\%. This era was known as the oil boom. Up to 1997, Indonesia still experienced a positive economic growth. However, in mid-1998, Indonesia economic contracted minus $13.1 \%$. The crisis was getting worse, if added with the uncontrolled population growth rate and the unemployment rate. Economic fluctuation created its own consequences, such as the changing of labor market structure that brought social economic political consequences. For example, the economic was squeezing, both in size and value. As a result, many factories and businesses had to do efficiencies. One policy that had to be conducted for efficiencies was the reducing of production cost. The reducing of production cost also meant as reducing human labors. Therefore, many employees had to seek another job. The competition in seeking jobs was getting difficult, not only because of that the economic condition experienced a negative growth but also the growth of jobs seekers made it worse. Statistic Bureau Data in February 2011 shows the Indonesia total labor force reached 119.4 million and from that number 111.3 million had jobs, which means that there was 6.80 percent of unemployment rate or equivalent to 8.1 million unworked labors. Another surprising fact, there were 93,601,800 college graduates who were unemployed (BPS, 2011). This figure was higher than in 2006 where there were 670,000 Bachelor degree and diploma graduates who were unemployed (Tempo, 2007). There are at least five factors causing unemployment in Indonesia. Firstly, the number of jobs available and the number of job seekers are not in balance. The number of job seekers is bigger than the available jobs. Secondly, there is a mismatch between the skills owned by job seekers with the skills needed by the labor market, in other words there is a misleading of education purposes with employers purposes. Thirdly, there are poverty problems, which force many poor students not to continue their education because of their economic hardship. As a result, it will cause of unskilled labor. Fourthly, the economic recessions that were followed by the global financial crisis, made many companies that had to cut off their production. As consequences, the companies reduced the number of workers, which resulting many unemployed people. The last caused is urbanization. Once a region is created as a center of economic, many people surrounding that region will come and try to get jobs. However, this region has limited resources to support all the people. Therefore, some of them are not survive and do not get appropriate jobs. That condition also creates social tension such as the increase of criminal rate and the rapid sprout of slump area.

The common sense in the public assumption is that a university graduate student is intended as "a beggar” for work. This assumption occurs because the learning system applied in various universities are mostly focus on how to prepare students to graduate fast and quick acquire job, others not. Due to the availability of employment is very limited, as a result, the number of higher education graduates who unemployed increases. There are many educated people are unemployed. Based on the logic above, it could be seen that universities potentially contribute in the increasing of unemployment rate. It seems that universities as the center of change and innovation are failed. Universities as the center of education provide basic science then are commercialized by large vertically integrated businesses. In the USA case, university patenting grows rapidly compared to private firm patent, which means that the growing of basic science that mostly developed by universities could enhance economic growth (Powell \& Snellman, 2004). In addition, Gunasekara (2006) indicates that universities play an important role in advancement of regions to develop their government structure to create more simple bureaucratic services in order to drive contemporary economic environment. Resuming from the opinion above, Benneworth (2006) figures that university is a kind of an incubator for social construction, therefore the universities position is crucial and urgent in seeking unique access of sources and invest resources in knowledge-based growth. Drucker (1992) sees that universities create better economy and better quality of live, human need knowledge. Powell and Snellman (2004) point out that knowledge is the resources in solving problem. Howkins (2011) strengthens those opinions by saying that knowledge tends to empower people. The use of knowledge is call as knowledge economy (Powell, 2004). According to Milwar (2003), the knowledge-based growth could change the way of thinking of communities that affect to the using of natural resources and the mapping of economic production toward the government capacities in managing economic growth world-wide (Henry, Pollard, \& Benneworth, 2006). This knowledge could escalate opportunities for gaining stable and rising prosperity for advanced economies’ community (Henry et al., 2006). Florida (2005) defines more clearly about the knowledge economic or knowledge-based growth as a skill that is owned by human that using their creativity in optimizing the limited resources and managing abandon resources. In sort, knowledge economic could be defined as a skill 
that could see economy potencies and use the potencies that is had by using certain knowledge and technology. In other world, it is called innovation. According to Powell, W. W. and Snellman, K. (2004), there are two benefits of innovation. The first benefit is that innovation will result in cost reduction for goods in widespread use. The second benefit is that innovation will produce new goods and service. Despite the fact that university plays a significant role in determining the economic creativity and innovation, it also contributes in pushing the economy by supplying educated labor annually. It is yet to address how the university standardizes their curriculum and their graduate in wide range of jobs opportunity offering by businesses and employers. Through the description of knowledge economy theory and the university social function as the center of social changes in society, this writing demonstrates how Islamic higher education such UIN Sunan Ampel in resolving the unemployment by developing a good environment in university teaching process in creating entrepreneurs. Can entrepreneur be created? The UIN Sunan Ampel Surabaya as one of the higher educations under the Ministry of Religion Affairs has a duty to create graduates who are competitive both in local and international jobs market. This university founded on 5 July 1965, based on the Indonesian Ministry of Religion Affairs Decree Number 20/1965 as the state institute for Islamic Studies. Based on the Indonesian Presidential Decree Number 65/2013, since 1 October 2013 UIN Sunan Ampel has a wider responsibility not only as the centre for Islamic studies, but also has an authority to develop other social studies, science and technology. The vision of this Islamic university is to become a worldwide premier and competitive Islamic university. In order to achieve this vision, UIN Sunan Ampel has three missions as follows:

1) Providing a premier and competitive teaching and learning services on Islamic studies, multidisciplinary studies, science and technology;

2) Developing research on Islamic studies, multidisciplinary studies, science and technology that relevant toward community needs; and

3) Developing community engagement model based on religiosity and research.

In order to support those vision and mission, UIN Sunan Ampel creates institutional development paradigm called "integrated twin tower". This paradigm is developed based on the discourses between religion and science. A meeting point of the religion and science discourses is defined as the concept of two twin towers (twin towers). The logical thinking of this concept is based on the interpretation of Al-Quran and Hadith as the foundations of science. This concept emerges two tower of knowledge. The first tower is the knowledge tower of Islamic Studies that consists of Islamic Studies Theory and applied Islamic studies. The second tower is the knowledge that consists of natural sciences, social sciences, and humanities. The two towers are linked by the adoption of two disciplines. The adoption of both towers of knowledge creates new disciplines such the Islamic Sociology, Islamic Philosophy, Islamic Economics, Islamic Politics, Islamic Entrepreneur and so on.

With the intention of supporting the twin tower framework, the strategic steps have been developed by UIN Sunan Ampel. The steps are including the updating of the curriculum, the modernizing the higher education management, and the upgrading the university infrastructure such as constructing new buildings and other facilities. However, from the strategic steps that have been planned, there are several obstacles that have to be faced. There are two major constraints faced by UIN Sunan Ampel and other Islamic Higher Education, which are cultural and structural constraints. Cultural constraint starts from the polarization of the society into the traditionalist theologians and modernist theologians. Traditionalist religious scholars assume that they have to have a high skill in classic Islamic texts. In contrary, the facts show that the community perspective looks at the skill and ability of students who graduates from Islamic higher education have no adequate understanding in classical Islamic texts (yellow book—Kitab Kuning).

Another indication also shows that students who graduate from Islamic traditional boarding school or pesantren just become religious rituals officers, which just have expertise in chairing of tahlil, talqin, marhaban and others ritual things. On the other hand, the modernist theologians are assumed that if they have to have a high skill in capturing the empirical aspects of the various problems that arise in society. Nonetheless, in the reality, this group is often less understanding the context and substance of empirical matters of religion. In this matter, Islamic higher education institution seems weak in developing new knowledge, especially the non-Islamic Studies. However, the current trend is shown the increase of acculturation process of local knowledge (religious studies) with science and technology. For example, Japan and Korea could be said succeed in combining local wisdom and modern science frame. As a result, the development of knowledge and technology grow rapidly. In other words, the ability of a nation to develop new knowledge, new information, new technologies and new culture are open widely because of the acculturation process of local knowledge (religious studies) with science and 
technology. Western culture or the Japanese are the examples. Based on that trend, the role of Islamic Higher Education Institution must have critical interdisciplinary dialogue, which strengthens the knowledge. An academic discourse accommodates religious studies with science and technology.

\section{Solution That Is Offered}

Instead of forming entrepreneurs as independent and creative human resources, entrepreneurs also have function as agents of change that support personal and national economic prosperity. It is believed that entrepreneurship can improve the quality of higher education, especially higher education in four aspects. The first aspect, it will strengthen Islamic Higher Education Curriculum. For example, the entrepreneurial content that has inserted in offered curriculum or unit courses can make students more creative in developing basic knowledge and skills of certain subjects. For example, in teaching of Fiqh Ibadah (Worship principles) there is the concept of beatification/sanctification or Thoharo. By inserting entrepreneurial aspect at this lecture, then a student can develop or innovate technologies that make it easier for Muslims to do wudlu by providing wudlu machine. Machines are more economic to conserve water but still in accordance with the pillars of wudlu. The second aspect, it is believed that entrepreneurial institute or university can strengthen itself by creating sustainable finance system. Most of universities in Indonesia are very dependent on the government budget. Just in case for example, there was less harmonious relationship between the government and parliament will result in the pending of budget list and programs that proposed. This is because the budget has not been approved by Parliament. If this happens, it can make difficulties to the university to carry out their activities normally. In order to anticipate this possible case, and to increase the sources of financing of the university, the university management could seek the funds by doing business activities that do not violate the law. For example, Indonesia is known as the largest Muslim country, in the month of Dzul-Hijjah for example, many people wish to conduct pilgrimage to Mecca. Fulfilled this demand, Islamic university such UIN Sunan Ampel can offer guidance services to perform Hajj and can hold a tour and travel for Hajj and Umrah organizing to Mecca. The third aspect, entrepreneurial content could be integrated on the one integrated Islamic education system from primary education system up to the higher education system. It is inevitable if the current economic education system from primary school to university is not integrated yet. Teaching system was carried out partially in each level of education. By introducing the concept of entrepreneurship at every level of education, then it can integrate economic education at all levels. The final aspect, the entrepreneurial education can reduce the negative image of Islam Higher Education which is probably known only as the producer of a preacher/speaker or even give birth to extremists or radical. With entrepreneurial contents, Islamic higher education will be known as one of the source entrepreneurs that support Indonesian economic growth. As a result, the negative image of religious radicalism can be reduced.

In order to achieve a better quality of higher education through inserting entrepreneurial contents into curriculum, UIN Sunan Ampel develops three differentiator's entrepreneurial concept. The first, UIN Sunan Ampel puts the Islamic value as the main idea in developing entrepreneurial skill that is offered. The second, UIN Sunan Ampel bridges between Islamic tradition and global modernity in order to develop the cultural awareness; and the last but not least concept, UIN Sunan Ampel develops education system that could provide education services with low budget but has excellent graduate. In some term, this effort called as "frugal innovation".

The planned staging is based on targeting area that projected. There are two staging that are proposed; regional expansion and national expansion. The regional expansion is developed through promotion visit to all regions; conducting an education exhibition and running the business incubators regionally. The national expansion that proposed is based on three activities: Firstly is by conducting researches for potential targeted provinces outside of East Java. Secondly is developing a networking with related ministries and state agencies; and lastly is developing a good relation with the national parliament members. Beside that in more detail, the proposed four years staging is divided into four programs. Entrepreneurial research program, university business unit program development, university teaching curriculum development, student entrepreneurial club as extracurricular, and university outreach programs. Those programs are resumed in 13 single programs that could be implemented in four years with the fifth years as reflection and evaluation of the whole program and setting the strategic plans for the next four years.

Since the declaration as an Islamic University, UIN Sunan Ampel has a wide market compared with previous status as an Islamic Studies Institute. Previously, the Sunan Ampel market concentration is the alumni of Pe- 
santren and East Javarural area. By the wider mandate from the Presidential Decree number 65/2013, UIN Sunan Ampel market copes both pesantren and high school graduates, rural area and urban area. The proposed vehicle is sustainable business concepts through four years' programs and eight years' programs. The business concept that is adopted should be pro-poor, environmental friendly and in accordance with the national development plan. The business concept is divided into three programs. First is the internal capacity building (Teaching, Research, Outreach); Second is redesigning the marketing concept; and the last, is developinga wider networking. The economic logic that is tried to develop is devided into three categories. The first category is that Sunan Ampel would have better reputation among Indonesian universities. The evidences that Sunan Ampel have better reputation are: Many community members that use Sunan Ampel services, such as extra fees for internship program, charging for services in the incubators and charging any Islamic entrepreneurship consultation. The second category is that Sunan Ampel would obtain financial income from their activities such as offering research finding to industries and enterprises and optimizing the income from the institute business units. The third is that UIN would have a great networking and counterpart. The great networking and counterpart could be seen from the support that is received from others such as getting program grants from several ministries. However, before implementing those strategies, UIN Sunan Ampel at least needs three conditions that should be done. The first, this Islamic University needs to improve the standard of students' recruitment and both administrative and academic staff recruitment. The recruitment quality should be put as main consideration in regard to have a better quality of university resources. The recruitment processes require a more rigorous selection of input and better structured for both prospective students and prospective academicians. The recent recruitment process does not cover the cognitive aspect such emotional intelligence, cultural intelligence, maturity or character. Furthermore, the current recruitment test has not been tested for reliability or validity. By having a cognitive evaluation to the prospectus students and staff will give at least three benefits. Firstly, the university human resources department will be easier to put new recruits based on the university needs. Secondly, a new student who has a high quality cognitive skill tends to easily to adapt with the higher education system learning process. As we know the learning process in university is based on independent study model. The last advantages is that by having a good recruitment both staff and student will result in better university atmosphere which could result in productive research that could be use in creating better living environment in community.

The second, UIN Sunan has to encourage their academics to develop their teaching skills and methods. Beside the teaching process, the university academicians have to increase their research to become more implemental and practical. As a result of this work, students should be provided with clearer and more systematic study schedules and review programs, and more clearly articulated formative assessment.

The last thing that should be prepared is to pursue the community support. In an developing UIN Sunan Ampel as a centre of excellence in community development and sustainable education system, university have to create a breakthrough communication technique in order to pursue the industry, business and community to involve in the process. For example, by having a good communication with industry and business, university could play as a partner for industry and business in doing their corporate social responsibility program in the community. The business and industry provide the fund and material and the university provides the human resources.

\section{Technical Implementation of the Solution Offered}

There are two approaches in implementing entrepreneurial curriculum through teaching unit. First approach is the creating student organization that focusing in entrepreneurial as extracurricular. In this method, entrepreneurship is built as a student activity unit. This activity involves students who have same passion and goal to become entrepreneurs. This is a passion to do innovative and creative action by creating business opportunities. The innovation and creativity should not against the manifestation of Sharia law. Second approach is the putting the entrepreneurial contents in the curriculum. The curriculum insertion is conducted based on the spirit of developing a better learning process through a gradual direct experience, structured and systematic method that will make the students able to achieve the aims and objectives of teaching that has been set.

There are three techniques in applying entrepreneurial content in curriculum. The first technique is by inserting the entrepreneurial content into one of the sub topics of unit course offered. For example, in the Department of Islamic Philosophy, there is a unit course called hermeneutic interpretation (Tafsir Hermeneutic). This unit 
could be inserted sub-topic such as the Quran economic verses interpretation or the hadiths of economy interpretation. The second technique is creating a new unit course. This method is introducing entrepreneurship unit courses as new courses in existing courses. The third technique is by developing a new specialization in entrepreneurship. This method offers some units that should be taken electively in order to fulfill the minimum requirement in entrepreneurial specialist.

\section{The Lessons}

The entrepreneurship concept and higher education aims meet in the process of encouraging people (students) to be more creative and innovative with their existing capital possessed. In Indonesia cases where the population is the third biggest in the world, a higher education graduate still struggle in joining in the market jobs. Beside educational background, experiences and personal esteem are the main components in obtaining jobs from the jobs providers. UIN Sunan Ampel as higher education institution has experienced in preparing the students in facing a competitive jobs market. The UIN Sunan Ampel road map in preparing their graduate is depicted on Figure 1. By having those five aspects, UIN Sunan Ampel is expected to provide adequate process in preparing their students for entering the job market. The first aspect that becomes main consideration is that UIN Sunan Ampel has to have economic logic in developing their curriculum and programs offered. By having a good economic consideration, the cost and benefit of each action planned could be determined. The second aspect is the arena, where is the scope or targeted market of UIN Sunan Ampel. The third aspect is the determined vehicles that need to be employed, what kind of steps and stages that need to be done. The last is that UIN Sunan Ampel in offering education services should show the comparative advantages in their system. The UIN Sunan Ampel should able show the differentiation of the UIN Sunan Ampel has offered compared the other universities. At the broadest level, the strategic planning of UIN Sunan Ampel may have some limitation and handicap, however, those strategic planning created as a road show in achieving the Sunan Ampel to become World Class University through entrepreneurship. By having entrepreneurship aspect in UIN Sunan Ampel curriculum, it creates a wider opportunity not only for Islamic Studies, but also for the other social studies, science and technology to become more implemental and applicative in creating a better society. However, from the effort that has been created, sustainability aspects need to be considered. The sustainability aspects that are needed could be fulfilled if the university could answer to the following four questions. Does the university have a strategy to deal with problem occurs? Does the university strategy explore the key resources that they have? What are the elements that support the strategy? Does the university have adequate support?

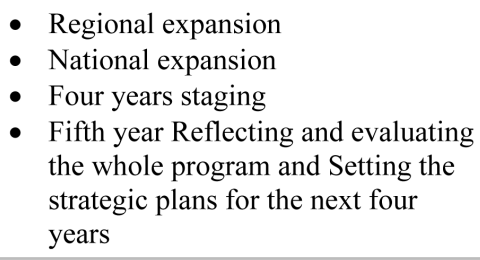

- Fifth year Reflecting and evaluating the whole program and Setting the strategic plans for the next four years

- Indonesian middle low economic class

- Rural area in EastJawaProvince

- Pesantren and Islamic higher schools graduate

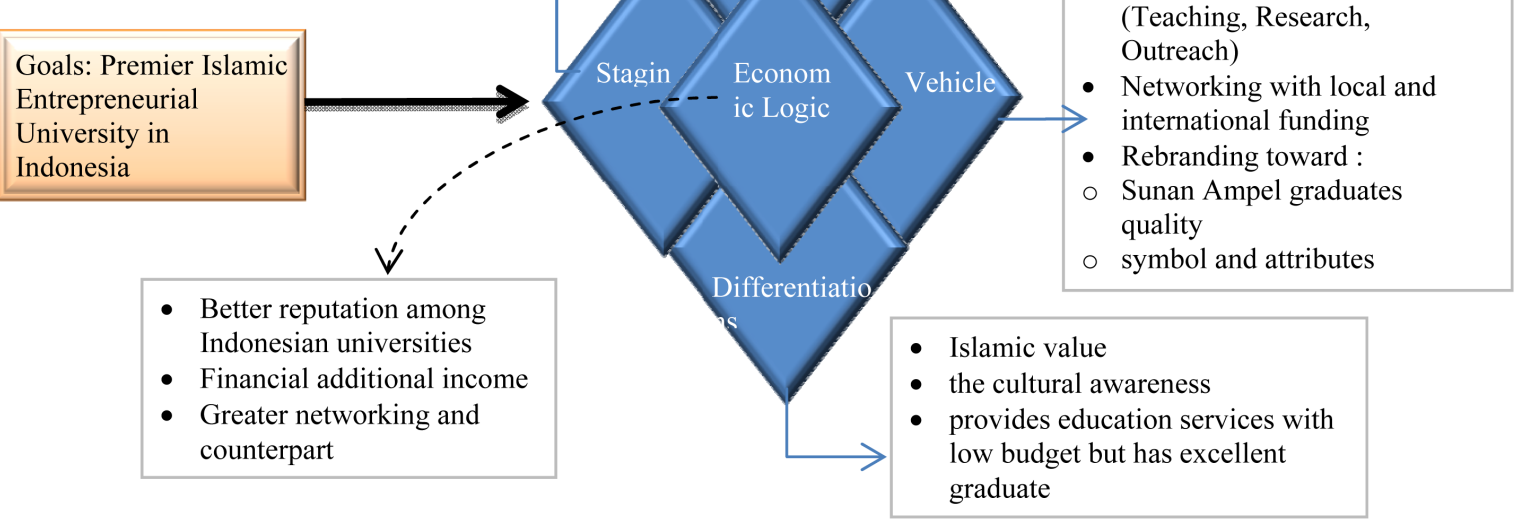

Figure 1. UIN Sunan Ampel strategic plan. 
This sustainability aspect questions above need to be answered properly in order to avoid the potential failure that could be occurs in achieving the higher education aims.

\section{References}

Benneworth, P. (2006). The Role of University Spin-Off Firms in Strengthening Regional Innovation Systems in Weaker Places. Territorial Production and Networks, 3.

BPS (2011). Data Strategis BPS. Indonesia Statistic Bureau. http://www.bps.go.id/65tahun/data_strategis_2011.pdf

Drucker, P. F. (1992). The New Society or Organization. Harvard Business Review, 95-104.

Florida, R. L. (2005). Cities and the Creative Class. Psychology Press.

Gunasekara, C. (2006). Reframing the Role of Universities in the Development of Regional Innovation Systems. The Journal of Technology Transfer, 31, 101-113. http://dx.doi.org/10.1007/s10961-005-5016-4

Henry, N., Pollard, J., \& Benneworth, P. (2006). 14 Putting Clusters in Their Place. Clusters and Regional Development: Critical Reflections and Explorations, 272.

Howkins, J. (2011). Creative Ecologies: Where Thinking Is a Proper Job. New Jersey: Transaction Publishers.

Powell, W. W., \& Snellman, K. (2004). The Knowledge Economy. Annual Review of Sociology, 30, 199-220. http://dx.doi.org/10.1146/annurev.soc.29.010202.100037 
Scientific Research Publishing (SCIRP) is one of the largest Open Access journal publishers. It is currently publishing more than 200 open access, online, peer-reviewed journals covering a wide range of academic disciplines. SCIRP serves the worldwide academic communities and contributes to the progress and application of science with its publication.

Other selected journals from SCIRP are listed as below. Submit your manuscript to us via either submit@scirp.org or Online Submission Portal.
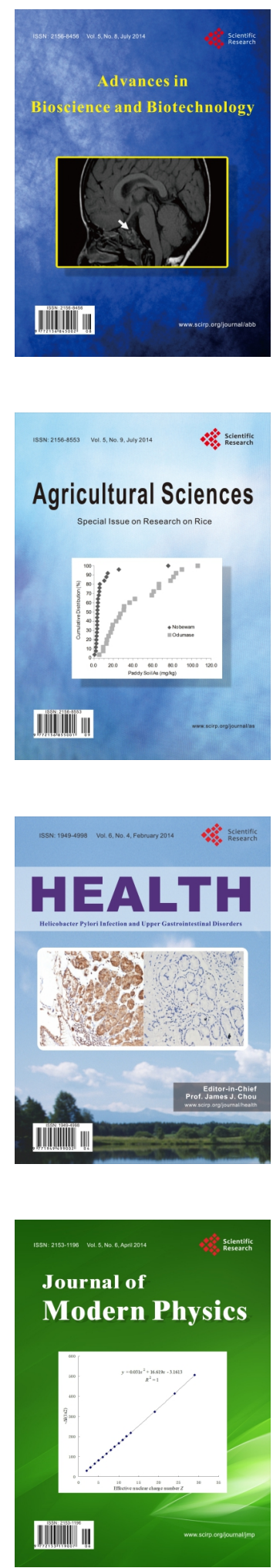
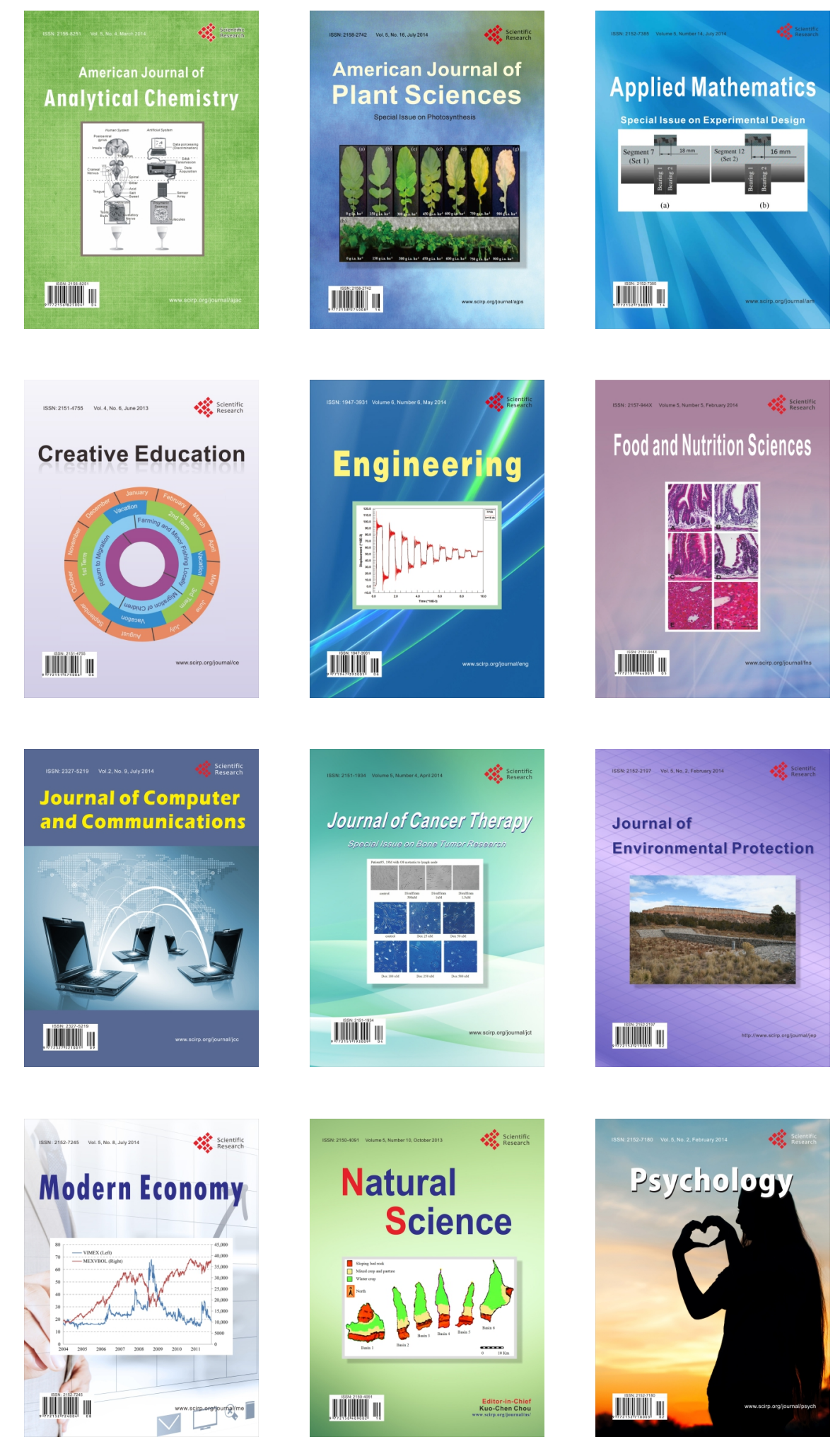